\title{
TRAUMATISM AND SOME ASPECTS OF TRAUMA CARE IN TRANSCARPATHIAN REGION AS A PART OF PUBLIC HEALTH
}

DOI: 10.36740/WLek202005117

\author{
Valeriya V. Brych, Hennagy 0. Slabkiy, Mykhailo M. Vasylynets, Mariana M. Dub \\ STATE HIGHER EDUCATIONAL INSTITUTION «UZHHOROD NATIONAL UNIVERSITY», UZHHOROD, UKRAINE
}

\begin{abstract}
The aim is to study and analyze the levels of general traumatism of the population, some aspects of trauma care in Transcarpathian region regarding administrative units. Materials and methods: Medical-statistical, graphic and biblio-semantic methods were used. The data of sectoral statistical reporting in Transcarpathian region for $2014-2018$ formed the base of the study.

Results: It is determined that the highest rates of traumatism (over 470 per 10 thousand population) are characteristic for the eastern districts of the region; the average indicators (260-470 per 10 thousand population) - for the northern and southern ones, and the lowest (less than 260 per 10 thousand population) - for the central and western parts of the region. The inequality of distribution of traumatological beds in the region in relation to the levels of injury in the administrative territories was determined.

Conclusions: With the established tendency to decrease of general traumatism in Transcarpathian region for the period 2014-2018, significant inequalities of the specified indicator and inconsistency of traumatological beds availability in the administrative territories were revealed.
\end{abstract}

KEY WORDS: traumatism, Transcarpathian region, trauma care.

Wiad Lek. 2020;73(5):931-936

\section{INTRODUCTION}

An important goal of each state and its society is to ensure sustainable public health, which involves fulfilling the key objectives identified by the Regional Office for Europe of the World Health Organization (WHO) in the European Action Plan for Strengthening Public Health Capacities and Services [1]. The first operational function of public health is "Epidemiological surveillance and assessment of health and well-being of the population". This feature assesses the health of local communities, identifies health issues and inequalities of specific populations, identifies needs, and plans action based on objective data, and provides trauma surveillance as one of the items [2]. It is well known that traumatism is the third leading cause of mortality in WHO European Region, and it threatens economic and social development [3]. Studies of changes over time, both between countries and domestically, show significant trends in the reduction of trauma in recent decades. Despite the downward trend in risk, relative social inequality in trauma remains a public health problem in the European Region [4].

WHO notes that injuries are a major cause of death for people aged 5-49, and mortality from injury is 2.4 times higher in low- and middle-income countries compared to high-income countries [5]. In Europe, there is a huge breakdown in social, economic, commercial, physical, climatic, environmental, geographical and political determinants, which leads to inequality in trauma rates between and within countries [6].

In Ukraine, the issue of traumatism is also important. According to the Department of Emergency Management of the State Emergency Service of Ukraine for 12 months of
2018, 1 million 660 thousand 954 accidents of non-productive nature were registered in Ukraine, as a result of which 1 million 664 thousand 222 people were injured. The smallest number of non-productive accident victims $-1.17 \%$ of the total - was registered in Transcarpathian region (19 thousand 505 people). At the same time, according to the statistical guide "Network of Institutions and Main Indicators of the Health Care System of Transcarpathian Region in 2018", the level of total traumatism in the region was 355.3 per 10 thousand population [7]. The most western region of Ukraine is of particular interest because it is on the border with 4 European countries and has specific geographical features.

The total level of injury among the whole population in Transcarpathian region over the 5 years, since 2014 decreased by $7.5 \%$. This period was characterized by an increase in the share of domestic injuries, a decrease in street and minor fluctuations in road, sports and industrial types of traumatism [8]. These data require more detailed study in order to plan public health interventions at the regional level.

\section{THE AIM}

The aim is to study and analyze the levels of general traumatism of the population, some aspects of trauma care in Transcarpathian region regarding administrative units.

\section{MATERIALS AND METHODS}

Medical, statistical, graphic, and biblio-semantic methods were used in the study. The data of the sectoral statistical 
reporting in Transcarpathian region constituted materials of the study. Separate indicators of trauma care in the region by administrative units (availability of hospital beds for trauma-suffering patients) are analyzed. The application of these methods in the study was reviewed and approved by the committee on ethics of state higher educational institution «Uzhhorod National University» (protocol No. 3 of December 11, 2020).

\section{RESULTS}

In the course of the study, the indicators of general traumatism of the population of Transcarpathian region and administrative territories were studied and analyzed. The obtained data are presented in table I.
The analysis of indicators given in Table 1 show a tendency to decrease the levels of injuries for the period of 2014-2018, both in the region as a whole (Fig. 1) and in separate administrative units (Fig. 2).

Only one administrative unit - Rakhiv district - saw a gradual annual reduction in the level of traumas within the range of 1.6-4.2\%: from 597.2 per 10 thousand population in 2014 to 535.6 per 10 thousand population in 2018 . The tendency to decrease the levels of injuries for the period 2014-2018 is established in 9 administrative units (64\%): Vynohradiv, Volovets, Irshava, Mukachevo, Perechyn, Svaliava, Uzhhorod, Khust districts and city of Uzhhorod. At the same time, in each of these districts there was an increase in the number of injuries in certain years - mainly in 2016 and 2017.

Table I. Traumatism in Transcarpathian region, 2014-2018 (per 10 thousand population).

\begin{tabular}{cccccc}
\hline Administrative territory & $\mathbf{2 0 1 4}$ & $\mathbf{2 0 1 5}$ & $\mathbf{2 0 1 6}$ & $\mathbf{2 0 1 7}$ & $\mathbf{2 0 1 8}$ \\
\hline Transcarpathian region & 384,1 & 377,1 & 388,1 & 359,1 & 355,3 \\
\hline Berehove district & 413,1 & 426,7 & 467,2 & 451,8 & 454,8 \\
\hline Velykyi Bereznyi district & 302,1 & 245,3 & 277,6 & 313,5 & 316,3 \\
\hline Vynohradiv district & 455,8 & 454,4 & 516,3 & 490,6 & 406,8 \\
\hline Volovets district & 354,4 & 364,7 & 384,3 & 339,0 & 304,9 \\
\hline Irshava district & 214,1 & 261,7 & 233,9 & 197,3 & 179,3 \\
\hline Mizhhirya district & 445,6 & 408,5 & 430,0 & 466,6 & 474,7 \\
\hline Mukachevo district & 284,8 & 253,8 & 281,4 & 218,5 \\
\hline Perechyn district & 352,4 & 368,1 & 436,8 & 505,3 \\
\hline Rakhiv district & 597,2 & 582,1 & 572,6 & 559,1 \\
\hline Svaliava district & 313,1 & 340,7 & 331,4 & 235,1 \\
\hline Tiachevo district & 510,4 & 476,5 & 533,2 & 456,4 \\
\hline Uzhhorod district & 228,1 & 125,5 & 119,9 & 128,1 \\
\hline Khust district & 316,3 & 299,6 & 317,5 & 294,9 \\
\hline City of Uzhhorod & 459,8 & 455,2 & 426,7 & 441,5 \\
\hline
\end{tabular}

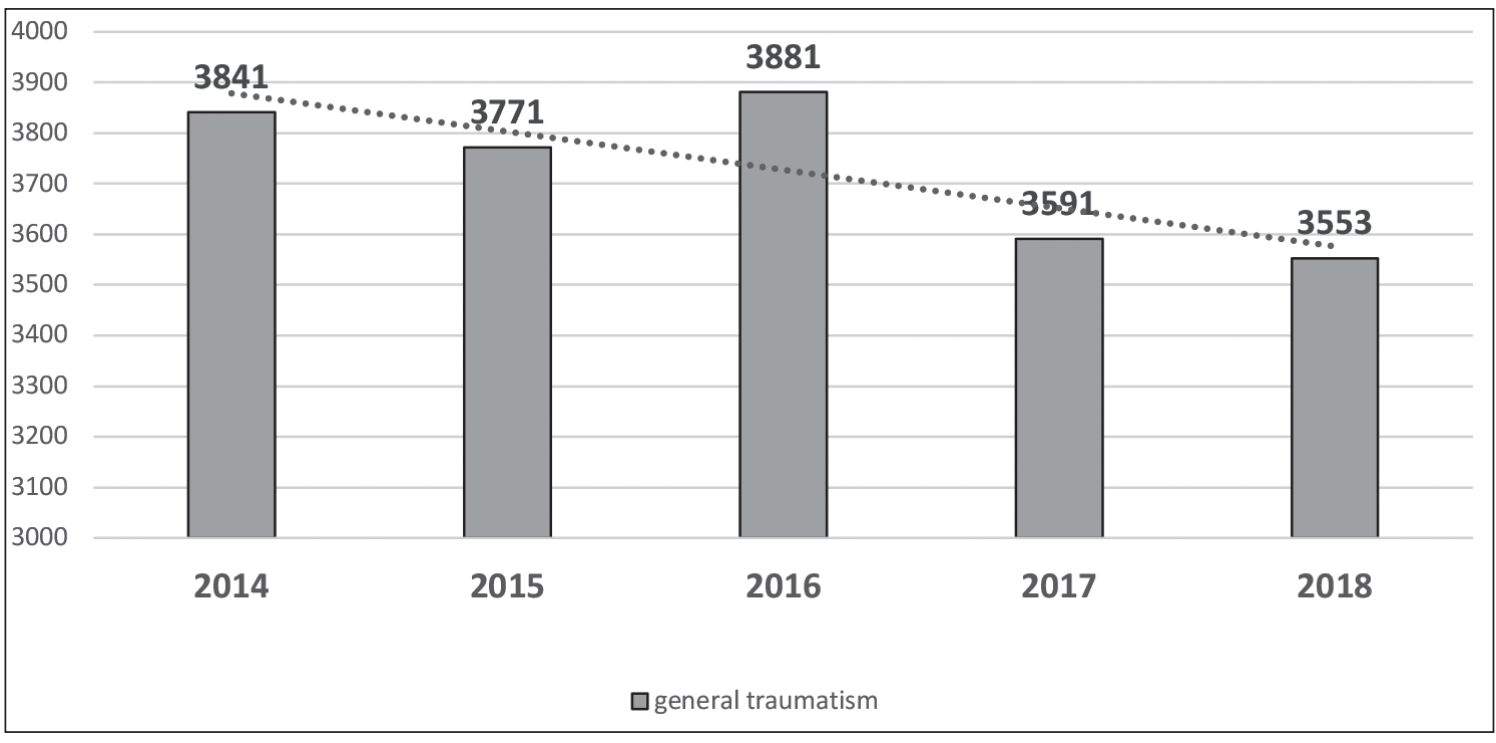

Fig. 1. Dynamics of general traumatism in Transcarpathian region for the period 2014-2018 (per 10 thousand population) 


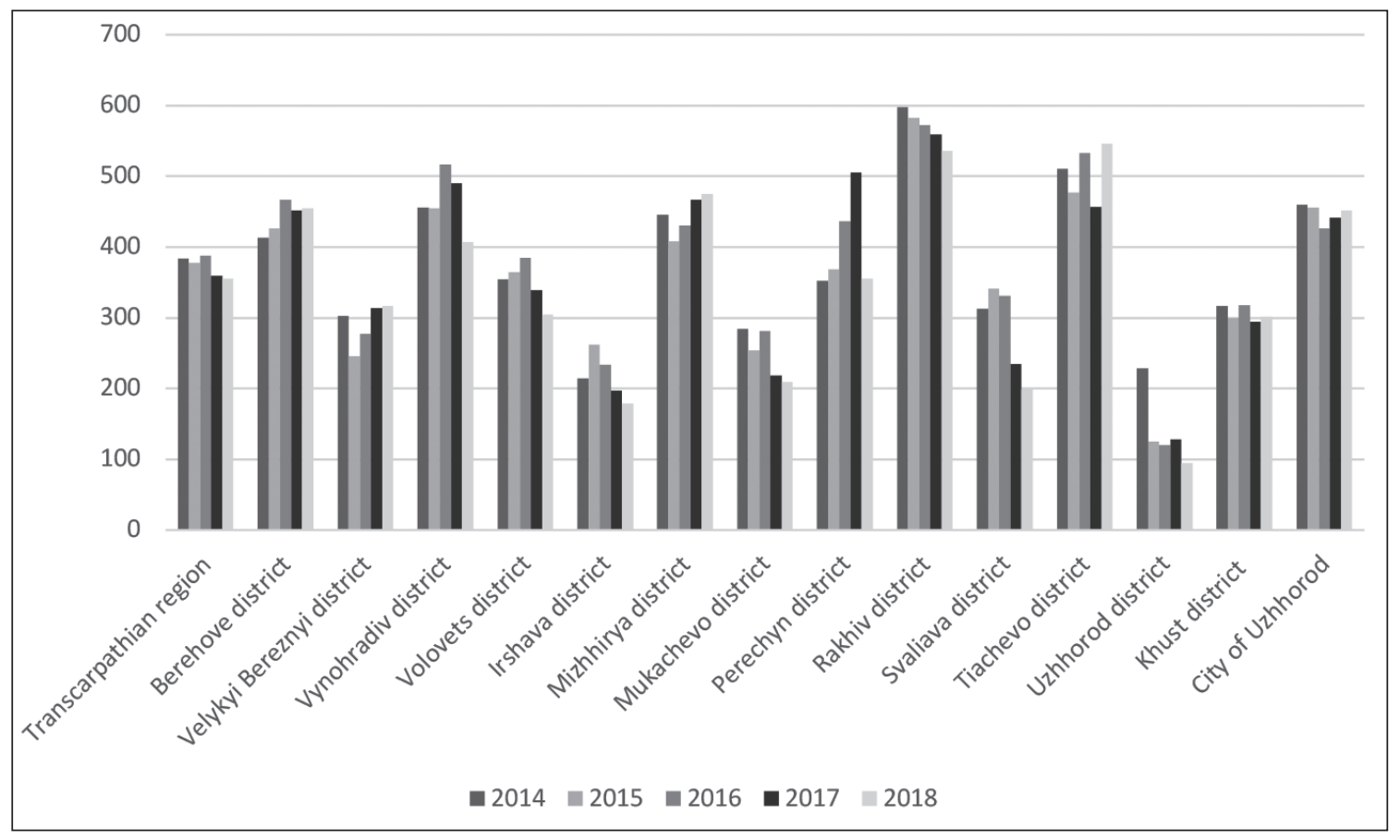

Fig. 2. Dynamics of general traumatism in the context of administrative territories of Transcarpathian region for the period 2014-2018 (per 10 thousand population)

In order to better understand the differences in territorial traumatism rates, a comparison was made of the average levels of injuries of administrative territories with the average regional indicator over a 5-year period (2014-1018), taking into account the average deviation. Thus, it was determined that at an average regional figure of traumatism 365,2 per 10 thousand population the value of the average deviation was 102,9. Accordingly, regions with a low level of traumatism are classified as having a figure below 260 per 10 thousand population, for regions with a high level the figure is higher than 470 per 10 thousand population. Accordingly, the regions with average traumatism rates include those for which the average traumatism rate is within the range of 260-470 per 10 thousand population.

Comparison of average traumatism rates by districts of the region for 2014-2018 is presented in fig. 3 .

As can be seen from the indicators in Fig. 3 the highest average rates of traumatism were registered in 2014-2018

Table II. Provision of traumatological beds in Transcarpathian region, 2014-2018 (absolutely and per 10 thousand population)

\begin{tabular}{cccccccccccc}
\hline \multirow{2}{*}{ Administrative territory } & \multicolumn{2}{c}{$\mathbf{2 0 1 4}$} & \multicolumn{2}{c}{$\mathbf{2 0 1 5}$} & \multicolumn{2}{c}{$\mathbf{2 0 1 6}$} & \multicolumn{2}{c}{$\mathbf{2 0 1 7}$} \\
\cline { 2 - 10 } & a6c. & \%o & a6c. & \%o & a6c. & \%o & a6c. & \%o & a6c. & \%o \\
\hline Transcarpathian region & 392 & 3,1 & $397^{*}$ & 3,16 & 390 & 3,1 & 399 & 3,2 & 399 & 3,2 \\
\hline Berehove district & 30 & 4,0 & 30 & 4,0 & 30 & 4,0 & 30 & 4,0 & 30 & 4,0 \\
\hline Velykyi Bereznyi district & 12 & 4,5 & 12 & 4,5 & 7 & 2,6 & 7 & 2,6 & 7 & 2,6 \\
\hline Vynohradiv district & 40 & 3,3 & 40 & 3,3 & 40 & 3,3 & 40 & 3,3 & 40 & 3,3 \\
\hline Volovets district & 13 & 5,3 & 13 & 5,3 & 13 & 5,3 & 13 & 5,3 & 13 & 5,3 \\
\hline Irshava district & 30 & 3,0 & 30 & 3,0 & 30 & 3,0 & 30 & 3,0 & 30 & 3,0 \\
\hline Mizhhirya district & 17 & 3,6 & 17 & 3,6 & 17 & 3,6 & 17 & 3,6 & 17 & 3,6 \\
\hline Mukachevo district & 50 & 2,7 & 45 & 2,4 & 45 & 2,4 & 45 & 2,4 & 45 & 2,4 \\
\hline Perechyn district & 17 & 5,3 & 17 & 5,3 & 15 & 4,7 & 15 & 4,7 & 15 & 4,7 \\
\hline Rakhiv district & 38 & 4,1 & 38 & 4,1 & 38 & 4,1 & 38 & 4,1 & 38 & 4,1 \\
\hline Svaliava district & 20 & 3,7 & 20 & 3,7 & 20 & 3,7 & 24 & 4,4 & 24 & 4,4 \\
\hline Tiachevo district & 40 & 2,3 & 40 & 2,3 & 40 & 2,3 & 40 & 2,3 & 40 & 2,3 \\
\hline Uzhhorod district & - & - & - & - & 15 & 1,9 & 20 & 2,8 & 20 & 2,8 \\
\hline Khust district & 50 & 3,9 & 50 & 3,9 & 45 & 3,5 & 45 & 3,5 & 45 & 3,5 \\
\hline City of Uzhhorod & 35 & 3,1 & 35 & 3,1 & 35 & 3,1 & 35 & 3,1 & 35 & 3,1 \\
\hline
\end{tabular}

\footnotetext{
* total number of beds includes those in hospital of departmental subordination (10 beds)
} 


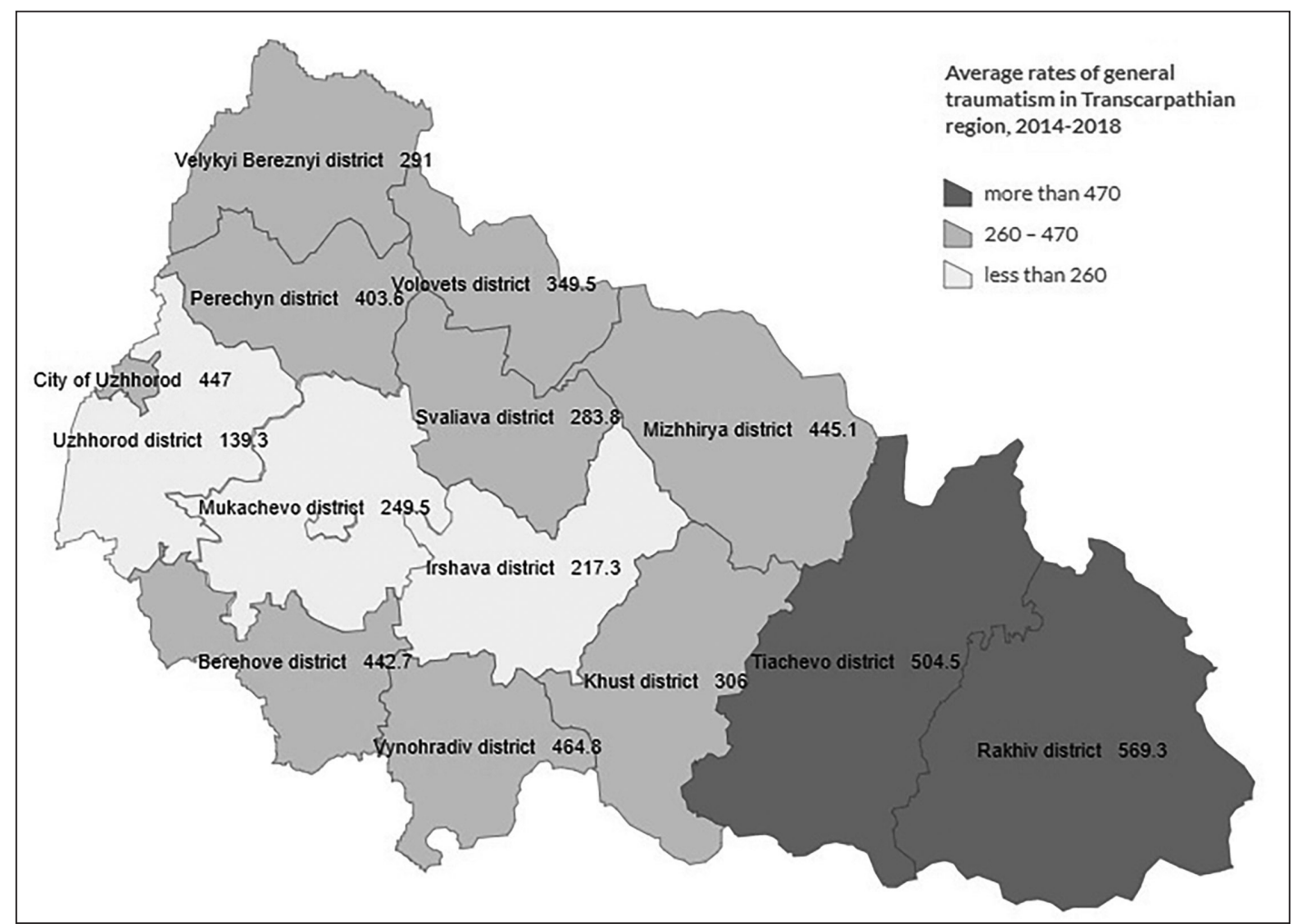

Fig. 3. Rates of general traumatism in Transcarpathian region, 2014-2018

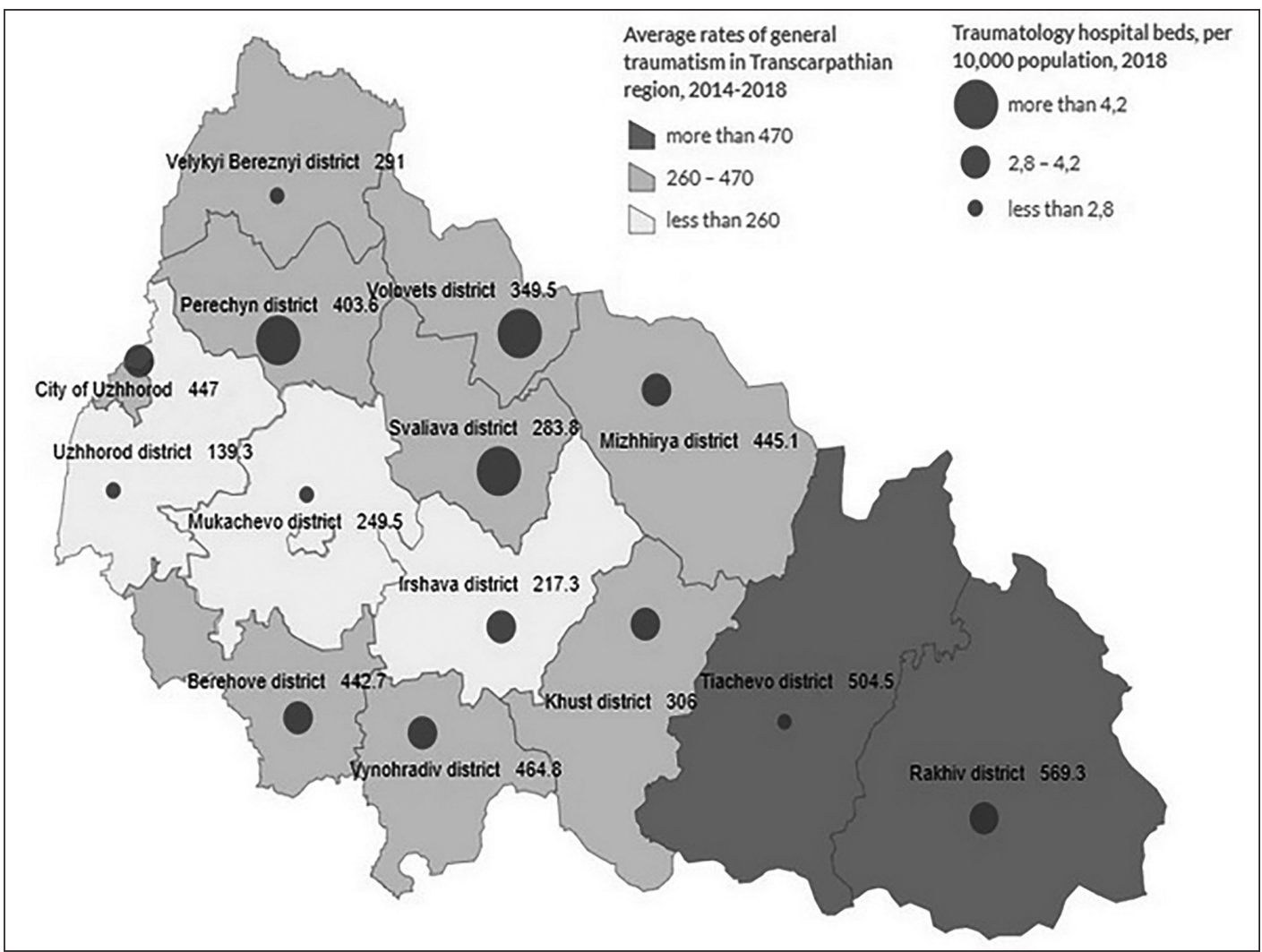

Fig. 4. Traumatology hospital beds, 2018

in the eastern districts of the region (Tiachevo, Rakhiv). Low level of traumatism is characteristic for the western and central part of the region (Uzhhorod, Mukachevo, Irshava districts). In the north and south of the region (Velykyi Bereznyi, Perechyn, Volovets, Svaliava, Mizhhirya, Khust, Vynohradiv and Berehove districts), as well as in the regional center (Uzhhorod), the level of traumatism in 2014-2018 was average.

The next stage was the study and analysis of individual indicators of traumatic assistance to the population of Transcarpathian region. In the region, inpatient trauma care was provided in all administrative units in district 
health facilities, as evidenced by the availability of traumatological beds at health care facilities (Table II).

For 2014-2018, the provision of traumatological beds in the region varied slightly and amounted to 3.1-3.2 per 10 thousand population. Beds were reduced in 2016 only in three administrative units with the approximation to regional indicator in Velykyi Bereznyi (by 42\%), Perechyn (by $12 \%$ ) and Khust (by 10\%) districts. It should be noted that the levels of general traumatism in Velykyi Bereznyi and Perechyn districts have been increasing since 2016. At the same time, traumatological beds (15) were opened in Uzhhorod district in 2016, and in 2017 their number increased by $33 \%$ (20 beds).

Comparison of traumatism rates in 2014-2018 with the state of availability of traumatological beds at the end of 2018 regarding districts of the region is presented in Fig. 4.

When analyzing the data presented in Fig. 4 it is established that there is an inequality of distribution of traumatological beds in the area relative to the levels of injury.

\section{DISCUSSION}

Traumatism has significant medical and social importance for the state and each of its regions, since its spread affects the mortality rate, causes significant economic losses in production, leads to increased costs of medical care, rehabilitation treatment and maintaining the quality of life of individuals with disabilities.

Special attention has been given to the westernmost region of Ukraine, the Transcarpathian region, which is characterized by certain features: the predominance of rural population (63\%), borderline placement (with 4 other countries), a large number of villages with the status of mountain settlements, recurrent natural disasters such as floods, massive migration to other regions of Ukraine and abroad, and so on. The specific features of each region should be taken into account in developing injury prevention and trauma care measures [8].

The analysis of the above indicators revealed that only in half of the administrative territories ( 7 districts), during all the years of the study period, the levels of traumatism were below the average in the region: Velykyi Bereznyi, Volovets, Irshava, Mukachevo, Svaliava, Uzhhorod and Khust districts.

It should be noted that the marginal differences between the indicators in 2015-2017 were registered between Uzhhorod (94.9-128.1 per 10 thousand population) and Rakhiv (559.1-582.1 per 10 thousand population) districts, which constituted 4.4-4.6 times. In 2014, the marginal difference was 2.8 times: between Irshava (214.1) and Rakhiv (597.2) districts. And in 2018, for the first time the highest rate of traumatism was registered in Tiachevo district -546.1 per 10 thousand population, and the maximum difference with the lowest level in Uzhhorod district (94.2) was 5.8 times.

The highest rates of traumatism (over 470 per 10 thousand population) are typical for eastern districts of the region, but the availability of traumatological beds is insufficient there (in Tiachevo district -2.3 per 10 thousand population at the level of traumatism 504.5 per 10 thousand population).
Average rates of traumatism (260-470 per 10 thousand population) are determined for northern and southern administrative units, which are predominantly provided with traumatological beds at $2.8-4.2$ per 10 thousand population and above 4.2 per 10 thousand population. The lowest rates of traumatism (less than 260 per 10 thousand population) are characteristic for central and western parts of the region. The availability of traumatological beds in these administrative units is 2.4-3.1 per 10 thousand population and corresponds to the levels of traumatism. Therefore, the discrepancy of traumatological beds availability in accordance with the indicators of traumatism regarding administrative territories of the region was revealed.

Planning for the provision of traumatological care, and accordingly the provision of traumatological beds, should be carried out not on the principle of distribution by population but on the actual indicators of traumatism in separate administrative units. In addition, it is important to analyze certain types of injuries across administrative territories, which will allow planning of both the health care system and public health activities to prevent the occurrence of all types of traumatism and preserve the working capacity of the population in the region.

\section{CONCLUSIONS}

1. With the established tendency to decrease of the general traumatism in Transcarpathian region for the period 2014-2018, significant inequalities of the specified indicator in the administrative units were revealed.

2. It was found that the highest rates of traumatism (over 470 per 10 thousand population) are characteristic for the eastern districts of the region, the average rates (260470 per 10 thousand population) - for the northern and southern ones, and the lowest (less than 260 per 10 thousand population) - for the central and western parts of the region.

3. The discrepancy of traumatological beds availability in accordance with the indicators of traumatism regarding administrative territories of the region was found.

The analysis of the epidemiological situation of traumatism and system of providing trauma care is an important factor in planning the activity of health care system and preventive measures of public health care system.

\section{REFERENCES}

1. World Health Organization, European Action Plan for Strengthening Public Health Capacities and Services. Copenhagen: Regional Committee for Europe; 2012. Available from: http://www.who.int/ workforcealliance/knowledge/resources/Health2020_policy.pdf.

2. Slabkiy G.0., Myronyuk I.S., Shafranskiy V.V. Epidemiolohichnyi nahliad yak osnovna funktsiia hromadskoho zdorovia [Epidemiological supervision as the main function of public health]. Ukraine. Nation's Health. 2017; 4(45): 97-100. (UA)

3. Sethi D., Mitis F., Racioppi F. Preventing injuries in Europe: from international collaboration to local implementation. Copenhagen:WHO Regional Office for Europe; 2010. Available from: http://www.euro.who. int/en/publications/abstracts/preventing-injuries-in-europe-frominternational-collaboration-to-localimplementation. 
4. Sengoelge M., Leithaus M., Braubach M., Laflamme L. Are There Changes in Inequalities in Injuries? A Review of Evidence in the WHO European Region. International Journal of Environmental Research and Public Health. 2019; 16(4): 653. doi.org/10.3390/ijerph16040653

5. Aldridge E., Sethi D., Yon Y. Injuries: a call for public health action in Europe. Copenhagen: WHO Regional Office for Europe; 2017. Available from: (http://www.euro.who.int/__data/assets/pdf_ file/0018/348102/WH08_IJ_complete-web-version.pdf?ua $=1$.

6. Review of social determinants and the health divide in the WHO European Region: final report. Updated reprint 2014. Copenhagen: WHO Regional Office for Europe; 2014. Available from: http://www. euro.who.int/_data/assets/pdf_file/0004/251878/Review-of-socialdeterminants-and-the-health-divide-in-the-WHO-European-RegionFINAL-REPORT.pdf

7. Network of health care facilities and key performance indicators of health care system of Transcarpathian region for 2018. Transcarpathian Regional Medical Information and Analytical Center. Uzhhorod, 2019, p.152.

8. Brych V.V. Characteristics of traumatism of the population of Transcarpathian region. In: Slabkiy G.O., Bilak-Lukianchuk V.Yo., Brych V.V. et al. Current issues of health care and physical rehabilitation: collective monograph. Lviv-Toruń: Liha-Pres: 2019: 44-61.
The work was performed within the framework of Scientific Research Work "Scientific Supportfor Regional Health Care Reform" I Code 51A-2015, State Registration Number 0112U001923.

\section{ORCID and contributionship:}

Valeriya V. Brych - 0000-0003-3741-6002 ${ }^{A, B, C, D}$

Hennagy O. Slabkiy - 0000-0003-2308-7869 ${ }^{A, E, F}$

Mykhaylo M. Vasylynets - 0000-0002-4687-1472 C,D

Mariana M. Dub - 0000-0002-2737-960X ${ }^{A, B}$

\section{Conflicts of Interest:}

The Authors declare no conflict of interest.

\section{CORRESPONDING AUTHOR Valeriya V. Brych \\ Uzhhorod National University \\ Mytna str., 29, Uzhhorod, 88000, Ukraine \\ tel: +380505133562 \\ e-mail:valeria.bruch@uzhnu.edu.ua}

Received: 27.01 .2020

Accepted: 02.04 .2020

A - Work concept and design, B - Data collection and analysis, C - Responsibility for statistical analysis,

D-Writing the article, $\mathbf{E}$-Critical review, $\mathbf{F}$ - Final approval of the article 